\title{
Erratum to: Tree-grass coexistence in a flood-disturbed, semi-arid savanna system
}

\author{
Matthew F. Child - Sue J. Milton - W. Richard J. Dean • Marisa K. Lipsey • \\ James Puttick • Tessa N. Hempson • Gareth K. Mann • Hassan Babiker • \\ Jamshed Chaudrey • Glynis Humphrey • Grant Joseph • Nicola C. Okes • \\ Reda Potts • Thuli Wistebaar
}

Published online: 6 February 2010

(C) Springer Science+Business Media B.V. 2010

\section{Erratum to: Landscape Ecol DOI 10.1007/s10980-009-9409-x}

The author Richard W.J. Dean in the author list should read as W. Richard J. Dean.
There is a mistake with Figure 3: Figures 3a) and $3 b)$ should be swapped around.

The online version of the original article can be found under doi:10.1007/s10980-009-9409-x.

M. F. Child · S. J. Milton - W. R. J. Dean ·

M. K. Lipsey · J. Puttick · T. N. Hempson ·

G. K. Mann · H. Babiker - J. Chaudrey ·

G. Humphrey · G. Joseph · N. C. Okes ·

R. Potts - T. Wistebaar

DST/NRF Centre of Excellence at the Percy FitzPatrick,

Institute of African Ornithology, University of Cape

Town, Rondebosch 7701, South Africa

M. F. Child ( $\bowtie)$

Conservation science group, Department of Zoology,

University of Cambridge, Downing Street, Cambridge

CB2 3EJ, UK

e-mail: mattychild@gmail.com 